\title{
FENOMENA ALIH KODE DAN CAMPUR KODE DALAM ANGKUTAN UMUM (ELF) JURUSAN SINDANG TERMINAL_HARJAMUKTI CIREBON
}

\author{
Ayu Fauziyah ${ }^{1}$, Itaristanti ${ }^{2}$, dan Indrya Mulyaningsih ${ }^{3}$ \\ IAIN Syekh Nurjati Cirebon1,2,3 \\ Posel: ayufauziyah262@gmail.co.id
}

\begin{abstract}
Abstarck
His study aims to describe the form of transfer and code mixing in public transport (elf) SindangTerminal Harjamukti Cirebon Department. The qualitative descriptive approach used in this study is the elaboration of data in the analysis. The results obtained from this study are a form of code switching and code mixing in public transportation (elf) Sindang-Terminal Harjamukti Cirebon Department and its causes. The form of code switching includes internal code switching which includes code switching between languages and code switching between languages and external code switching. The cause of the occurrence of code switching is that the interlocutor has a different language background than the speaker, the speaker has a desire to respect his interlocutor who is older than him, and the limited use of the code. The form of code mixing includes code mixing in the repetition of words and kalusa, mixing code out at the level of phrases and idioms, and mixing mixed codes of baster forms. The reason for code interfering occurs when speakers want to be able to use more popular terms, speakers have a specific purpose and purpose in the conversation, to be just prestigious, and to adjust language use to the topic of conversation.
\end{abstract}

Keywords : the form of code switching; the factors that cause code switching; the form of code mixing; the causes of code interfering.

\begin{abstract}
Abstrak
Penelitian ini bertujuan untuk mendeskripsikan bentuk alih dan campur kode dalam angkutan umum (elf) Jurusan Sindang-Terminal Harjamukti Cirebon. Pendekatan deskriptif kualitatif digunakan dalam penelitian ini berupa penjabaran data dalam analisisnya. Hasil yang diperoleh dari penelitian ini adalah bentuk alih kode dan campur kode dalam angkutan umum (elf) Jurusan Sindang-Terminal Harjamukti Cirebon serta faktor penyebabnya. Bentuk alih kode meliputi meliputi alih kode internal yang mencakup alih kode antarbahasa dan alih kode antarragam bahasa serta alih kode ksternal. Adapun faktor penyebab terjadi alih kode adalah lawan bicaranya memiliki latar belakang bahasa yang berbeda penutur, penutur memiliki keinginan untuk menghormati lawan bicaranya yang berusia lebih tua darinya, dan keterbatasan penggunaan kode. Bentuk campur kode meliputi campur kode ke dalam pada tataran pengulangan kata dan kalusa, campur kode ke luar pada tataran frasa dan idiom, serta campur kode campuran bentuk baster. Faktor penyebab campur kode terjadi adalah penutur berkeinginan untuk dapat menggunakan istilah yang lebih populer, penutur memiliki maksud dan tujuan tertentu dalam pembicaraan, untuk sekadar bergengsi, dan penyesuaian penggunaan bahasa dengan topik pembicaraan.
\end{abstract}

Kata Kunci: bentuk alib kode; faktor penyebab alib kode; bentuk campur kode; faktor penyebab campur kode.

\section{PENDAHULUAN}

Bahasa memiliki peranan yang sangat penting dalam kehidupan bermasyarakat. Bahasa dijadikan sebagai sarana atau alat komunikasi dalam bermasyarakat. Seseorang untuk dapat menjalin hubungan yang baik dengan seseamanya, dapat saling memahami karakter satu dengan yang lainnya, berbagi pendapat serta pengetahuan tentunya membutuhkan alat dalam penyampaiannya, sehingga digunakanlah bahasa sebagai suatu sarana atau alat penyampai gagasan atau idenya. Menurut Itaristanti (2012:107), bahasa akanI tetap hidup apabila masih terdapat penuturnya. Tentu saja, penuturnya adalah masyarakat. Akan tetapi 
penutur sebuah bahasa tidaklah bersifat homogen melainkan heterogen atau beragam. Hal inilah yang menyebabkan timbulnya variasi bahasa.

Kota Cirebon merupakan salah satu kota yang berada di Provinsi Jawa Barat, Indonesia yang masyarakatnya mayoritas penutur bahasa Jawa. Namun, dalam kenyataannya berdasarkan pengamatan yang dilakukan Cirebon merupakan kota yang sebagian masyarakatnya menguasai dua bahasa dalam berkomunikasi atau dwibahasawan dan sebagian lain menguasai bahasa yang relatif sangat bervariatif dalam berkomunikasi yang disebut dengan multilingualisme. Bahasa yang digunakan, antara lain bahasa Jawa, bahasa Sunda, dan bahasa Indonesia. Berdasarkan pengamatan yang dilakukan terhadap masyarakat yang sedang berinteraksi dalam angkutan umum Sindang-Terminal Harjamukti antarpemakai bahasa yang bervariatif dapat menimbulkan terjadinya suatu kontak bahasa dalam diri penutur. Penggunaan bahasa yang bervariatif dapat menyebabkan terjadinya pemakaian dua bahasa oleh penutur secara bergantian yang disebut dengan alih kode dan pencampuran beberapa bahasa dalam berkomunikasi, campur kode. Hal demikian dapat terjadi karena seorang penutur mengalami kesulitan dalam berkomunikasi dengan lawan bicaranya yang berasal dari latar belakang yang berbeda, baik dari segi sosial maupun daerah penuturnya sehingga terjadilah penggunaan kode bahasa.

Menurut Mustikawati (2015:2), peristwa peralihan bahasa dan pencampuran bahasa menjadi suatu disiplin ilmu yang memiliki andil yang cukup besar dalam kaitannya dengan pemanfaatan bahasa terhadap seseorang atau sekelompok orang, baik pada masyarakat bilingual maupun masyarakat multilingual, misalnya di angkutan umum (elf). Dalam angkutan umum (elf) dikatakan menarik karena sangat langka yang meneliti mengenai alih kode dan campur kode dalam angkutan umum.

Sarana transportasi dijadikan tempat penelitian karena di dalamnya memuat kegiatan komunikasi, bahkan transaksi yang berasal dari wilayah yang bervariatif. Latar belakang pendidik yang berlainan serta status sosial masyarakat yang relatif berbeda dapat memicu timbulnya bahasa yang beraneka warna sehingga menimbulkan terjadinya peralihan bahkan penyelipan unsur bahasa lain. Fenomena di atas tentu menjadi daya tarik untuk melakukan penelitian terkait bentuk aih kode dan serta faktor penyebabnya pada interaksi antara sopir, kondektur, dan penumpang dalam angkutan umum (elf) Jurusan Sindang-Terminal Harjamukti Cirebon. Tujuan dilakukannya penelitian ini adalah untuk mendeskripsikan bentuk-bentuk alih kode dan campur kode dalam angkutan umum (elf) Jurusan SindangTerminal Harjamukti Cirebon serta faktor penyebabnya. Peneliti memilih meneliti peralihan bahasa atau alih kode dan pencampuran bahasa atau campur kode di angkutan umum Sindang Terminal harjamukti Cirebon karena belum pernah dilakukan penelitian campur kode dan alih kode di angkutan umum Cirebon. Selain itu, sangat sedikit yang meneliti mengenai alih kode dan campur kode di angkutan umum.

Menurut Dell Hymes (dalam Jendra, 2012: 74) "Code switching is the use of more than one language by communicants in the execution of a speach art" (Alih kode terjadi dalam suatu tuturan yang memakai bahasa sebagai sarana komunikasi lebih dari satu macam). Menurut Suandi (2014: 132), alih kode merupakan pergantian (perpindahan dari satu varian bahasa ke dalam bentuk satuan bahasa lainnya. Senada dengan pendapat di atas, secara lebih lanjut dan 
terperinci Chaer dan Agustina (2010: 106) menjelaskan alih kode dapat diartikan sebagai peristiwa peralihan bahasa dari satu ragam ke ragam lain.

Secara gamblang dan jelas Suwito (dalam Chaer \& Agustina, 2010: 114), mengemukakan terdapat dua macam jenis perpindahan bahasa yang terjadi di masyarakat, antara lain sebagai berikut.

1. Alih Kode Internal merupakan sebagai jenis peralihan atau perpindahan pengunaan bahasa yang dilakukan masyarakat tutur bentuk bahasanya berupa bahasa antarpenutur sendiri atau dalam satu wilayah atau satu negara.

2. Alih kode eksternal terjadi apabila terdapat suatu masyarakat penutur bahasa ketika sedang berkomunikasi atau bersosialisasi memakai dua macam lebih bentuk satuan bahasa dengan secara bertukar antara bahasa sendiri dengan bahasa asing.

Menurut Chaer \& Agustina (2010: 108-112), faktor-faktor yang berpotensi menimbulkan terjadinya peristiwa perpindahan atau peralihan penggunaan jenis bahasa satu ke jenis lainnya atau biasa disebut dengan alih kode adalah (1) pembicara atau penutur beralih kode dengan tujuan tertentu sesuai dengan kebutuhannya, (2) lawan bicara yang berbeda latar belakang bahasa dengan penutur dapat menyebabkan terjadinya peristiwa perpindahan penggunaan bahasa, (3) perubahan kondisi dan situasi karena munculnya orang ketiga yang menduduki fungsi sebagai penentu jenis atau ragam bahasa yang dilakukan penyelerasan terhadap suatu topik pembicaraan. Hal ini dilakukan dengan tujuan mengefektifkan dan membuat lebih terarah pembicaraan yang diselenggarakannya. Selanjutnya (4) perubahan situasi dari resmi ke situai yang tidak resmi, dan (5) berubahnya topik pembicaraan

Menurut Kholiq, Roekhan, dan Sunaryo (2013: 2), yang dimaksud dengan campur kode yaitu gejala penyisipan bentuk satuan bahasa baik yang berasal dari dalam maupun dari luar. Senada dengan pendapat tersebut Rokhman (2013: 39), menyebutkan bahwa pencampur kode diartikan sebagai suatu bentuk fenomena pemakaian dua jenis atau lebih bahasa dengan saling menyisipkan antarunsur bahasa yang satu ke yang lainnya.

Dalam bukunya, Suandi (2015: 140) membedakan campur kode menjadi tiga bentuk sebagai berikut.

1. Jenis campur kode ke dalam (inner code mixing) terjadi apabila terdapat penggunaan pencampuran bahasa dalam berkomunikasi dengan menyelipkan antarunsur bahasanya dan penyerapan unsur bahasannya masih satu keturunan atau dengan bahasa lainnya maka dinamakan dengan campur kode ke dalam (inner code mixing).

2. Campur kode ke luar (outer code mixing) merupakan penggunaan pencampuran beberapa bahasa dalam berkomunikasi dengan menyelipkan unsur bahasa yang berbeda dengan bahasa dasarnya, penyerapan unsur bahasanya berupa bahasa asing.

3. Campur kode campuran (bybrid code mixing). meliputi penggunaan pencampuran pemakaian bahasa yang bervariatif di dalamnya terdapat penyisipan jenis unsur bahasa asli atau bahasa sekerabat dan bahasa asing.

Menurut Jendra (dalam Suandi, 2014: 141) melalui faktor kebahasaan yang terdapat di dalamnya, jenis campur kode terdapat beberapa macam, di antaranya sebagai berikut. 
1. Campur kode pada penyisipan tataran kata

Suatu kata dapat diartikan sebagai satuan bahasa yang terkecil menduduki satu fungsi sintaksis (subjek, predikat, objek, dan keterangan). Campur kode pada tataran kata merupakan pencampuran bahasa yang lumrah terjadi di setiap pengguna bahasa. Campur kode pada tataran kata biasanya berwujud kata dasar.

2. Campur kode pada penyisipan tataran frasa

Frasa adalah satuan gramatikal bahasa memuat dua jenis atau lebih kata yang sifatnya tidak predikatif dan terbangun atas dua jenis atau lebih jenis kata yang unsurnya tidak melebihi tataran klausa. Frasa merupakan suatu satuan bentuk bahasa sesuai dengan tata bahasa berupa gabungan kata dan bersifat nonpredikat. Campur kode pada tataran frasa setingkat lebih rendah dibandingkan dengan campur kode pada tataran klausa.

3. Campur kode pada penyisipan tataran klausa

Menurut Chaer (2015: 231) Satuan bentuk sintaksis yang memuat mengenai deretan kata yang tersusun secara predikatif disebut dengan klausa. Penyisipan berdasarkan tataran klausanya berupa penyelipan satuan basaha yang sekurangnya memiliki dua fungsi predikatif atau fungsi predikatif.

Menurut Suandi (2015: 143-146), faktor yang mendasari atau menyebabkan terjadinya penggunaan penyisipan beberapa unsur kata dalam berkomunikasi atau campur kode adalah: (1) keterbatasan penggunaan kode, sehingga ketika proses sosialisasi berlangsung terjadi ketidakpahaman padanan satuan bahasa dasar yang dipakainya dan mencari padanan kata lainnya untuk digunakan. (2) Pemakaian bentuk istilah yang lebih populer dapat diukur dengan banyaknya masyarakat yang mengetahui kata tersebut. (3) Pembicara memiliki tujuan tertentu dalam berinteraksi sesuai dengan kebutuhannya. (4) Lawan bicara tidak begitu memahami bahasa yang dikuasi penutur sehingga memakai unsur bahasa yang sama. (5) Tempat tinggal pembicara dan waktu pembicaraan berlangsung menyebabkan terjadinya campur kode. (6) Modus pembicaraan, baik berupa modus lisan maupun tulisan. Modus pembicaraan jenis lisan dapat dilakukan melaui tatap muka, telepon, atau audio visual lain yang dalam penggunaan bahasanya lebih ke ragam nonformal. Modus pembicaraan jenis nonlisan atau tulisan berupa buku pelajaran, karangan bebas, surat-menyurut yang menggunakan bahasa yang terikat dengan kaidah atau disebut dengan ragam bahasa jenis formal. (7) Topik pembicaraan, (8) peranan dan maksud pembicaraan, (9) pemilihan ragam dan tingkat tutur bahasa sesuai dengan usia lawan bicaranya, (10) pembangkin rasa humor dalam peristiwa tutur. Berikutnya, (11) pokok pembicara, (12) untuk sekadar bergengsi, (13) hadirnya Penutur Ketiga.

\section{METODE PENELITIAN}

Pendekata yang digunakan dalam penelitian ini adalah metode deskriptif kualitatif. Menurut Sugiyono (2015: 29), penelitian deskriptif berisi mengenai kegiatan penganalisisan terhadap suatu data melalui bentuk penjabaran data yang sudah terkumpul. Metode yang digunakan dalam penelitian ini, meliputi metode simak dan metode cakap. Menurut Mahsun (2017: 92), metode simak dilakukan untuk menyimak penggunaan bahasa. Teknik yang digunakan dalam metode ini adalah teknik simak bebas libat cakap, yaitu seorang peneliti hanya berperan sebagai pengamat atau pendengar penggunaan bahasa oleh para informan, teknik 
catat, dan teknik rekam. Selanjutnya, metode cakap berupa bentuk percakapan dalam pengambilan data. Adapun teknik yang digunakannya, meliputi teknik cakap semuka merupakan percakapan yang dilakukan antara peneliti dan informan dilakukan secara langsung atau dengan bertatap muka, teknik rekam, dan teknik catat.

Sumber data dalam penelitian ini adalah sumber data primer, yaitu data yang diperoleh langsung dari subjek peneliti dengan menggunakan instrumen-instrumen yang telah di tetapkan (Azwar, 2009: 91). Dalam hal ini berupa bentuk-bentuk satuan bahasa alih kode dan campur kode pada interaksi antara penumpang, sopir, dan kondektur di angkutan umum Sindang-Terminal Harjamukti Cirebon. Instrumen yang digunakan dalam penelitian ini meliputi lembar instrumen observasi dan bentuk instruman wawancara. Penelitian ini dalam penganalisisan datanya dengan memanfaatkan metode dalam kajian bahasa. Metode yang dipakai dalam penganalisisan data berupa metode dan metode introspeksi. Metode padan merupakan analisis data dengan alat penentu yang digunakan berada di luar kebahasaan (Sudaryanto, 2015: 138). Adapun metode intospeksi digunakan sebagai metode penganalisisan data gunu untuk memanfaatkan intuisi kebahasaan peneliti yang meneliti bahasa bahasa yang dikuasinya untuk menganalisis data (Mahsun, 2017: 107).

Menurut Sugiyono (2016: 246-247) kegiatan penganalisis penelitian dalam bentuk data kualitatif yaitu, (1) reduksi data dilakukan dengan mulai mengumpulkan data yang diperoleh pada interaksi antara penumpang, kondektur, dan sopir dalam angkutan umum (elf) jurusan Sindang-Terminal Harjamukti Cirebon, (2) klasifikasi data (3) deskripsi data, (4) penyajian data, dan (5) penarikkan simpulan.

\section{HASIL DAN PEMBAHASAN}

Berdasarkan hasil analisis data pada percakapan yang terjadi antara sopir, kondektur, dan penumpang dalam angkutan umum (elf) Jurusan Sindang-Terminal Harjamukti Cirebon ditemukan bentuk alih kode internal, yang meliputi alih kode antarbahasa dan antar ragam bahasa serta alih kode eksternal serta faktor penyebabnya, seperti pada data di bahwah ini.

\section{Alih Kode Internal}

Alih kode internal dapat diartikan sebagai jenis peralihan atau perpindahan pengunaan bahasa oleh seseorang dari bahasa asal atau bahasa daerah ke bahasa nasional maupun sebaliknya, dari bahasa asal ke bahasa asing ataupun sebaliknya. Alih kode juga dapat berupa perpindahaan penggunaan antarragam bahasa dari satu ragam bahasa ke ragam bahasa lainnya, peralihan antardialek dalam satu bahasa daerah, perpindahan penggunaan bahasa antarbeberapa ragam dan gaya yang terdapat dalam satu dialek (Suwito, 1983: 69). Adapun faktor penyebab terjadinya alih kode, yaitu lawan bicaranya memiliki latar belakang bahasa yang berbeda penutur, penutur memiliki keinginan untuk menghormati lawan bicaranya yang berusia lebih tua darinya.

\section{a. Alih Kode Internal Antarahasa}

pada percakapan berikut ini ditemukan fenomena alih kode internal antarbahasa berupa penggunaan dua bahasa secara bergantian dari bahasa Jawa ke bahasa Indonesia. Hal ini disebabkan karena lawan tutur yang terlibat memiliki latar belakang bahasa yang berbeda dengan penutur. Lawan tutur berasal Karang Sembung Cirebon yang 
merupakan masyarakat penutur bahasa Sunda dalam kegiatan sehari-harinya sedangkan penutur berasal dari Buntet Cirebon yang berbahasa ibu, bahasa Jawa.

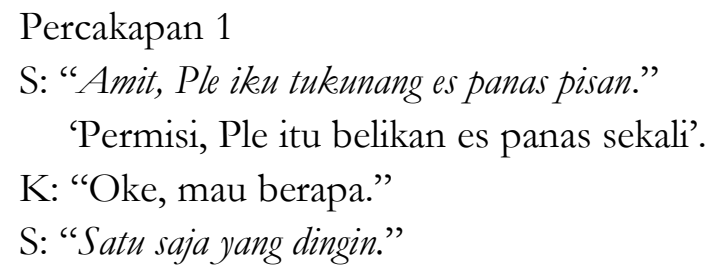

Interaksi yang terjadi antara sopir dan kondektur dalam angkutan umum terjadi pada siang hari. Hal ini dapat dilihat dari penggalan ungkapan sopir yang menyebutkan "panas sekali" dan cuaca panas biasanya terjadi di siang hari. Peristiwa tutur tersebut membahas mengenai permintaan sopir untuk membelikan minuman kepada kondekturnya karena sedang kehausan. Percakapan bermula saat sopir meminta tolong pada kondektur dengan menggunakan bahasa Jawa. Bahasa Jawa dipilihnya dalam membuka percakapan karena sopir terbiasa berkomunikasi dalam kegiatan sehari-hari dengan berbahasa Jawa, namun terkadang juga berbahasa Indonesia. Akan tetapi, kondektur menjawabnya dengan berbahasa Indonesia. Pemilihan bahasa Indonesia dilakukan karena kondektur hanya memahami maksud dari perkataan sopir namun tidak dapat berbicara dengan menggunakan bahasa Jawa. Setelah itu, sopir menjawabnya dengan beralih kode menggunakan bahasa Indonesia. Peralihan penggunaan bahasa Indonesia dilakukan karena kondektur memahami bahwa lawan bicaranya memiliki latar belakang bahasa yang berbeda sehingga digunakan bahasa yang dikuasai dan diketahui oleh keduanya sebagai bentuk penyesuaian agar komunikasi dapat berjalan dengan baik.

\section{b. Alih Kode Internal Antarragam bahasa}

Peralihan penggunaan bahasa dari bahasa Jawa ke Jawa Kromo terjadi pada percakapan berikut ibi. Alih kode ke bahasa Kromo dilakukan karena penutur beranggapan bahasa bahasa Jawa Kromo memiliki nilai rasa kesopanan lebih tinggi apabila dibanding dengan bahasa Jawa. Bahasa Kromo adalah bahasa halus yang biasa dipakai ketika penutur berbicara dengan lawan bicara yang lebih tua atau yang lebih berilmu daripadanya. Percakapan berikut ini merupakan contoh bentuk alih kode internal berupa perpindahan dari bahasa Jawa Cirebon ke bahasa Jawa Kromo yang disebabkan karena faktor tersebut.

Percakapan 2

P1: "Priben kabare? tambah lemue bae ya."

"Bagaiman kabarnya? Tambah gemuknya saja ya.

P2: "Alhamdulillah baik, lemu apae sih angger bae kaya kenen kah."

"Alhamdulillah baik, gemuk apanya sih tetap saja seperni ini kok'.

P1: "Angkone kuh arep mampir ning umah lamun ana Amnae sih."

"Niatnya sih mau mampir ke rumah kalau ada Amnanya sih'.

P2: "Nggih Mba, Amnae dereng wangsul."

Tya Mba, Amnanya belum pulang'.

P1: "Pangkat teng pundi sih Amnae?"

'Berangkat ke mana sih Amnanya'? 


\section{P2: "Teng Bekasi wiraose sih."}

Di Bekasi bilangnya sih'.

Peristiwa tutur tersebut terjadi antarpenumpang yang membahas mengenai kabar dan keinginan penutur untuk bisa bersilaturahmi dengan lawan bicaranya. Pada data tersebut ditemukan fenomena peralihan penggunaan antarragam bahasa Jawa yang terjadi dari bahasa Jawa ke bahasa Jawa Kromo. Penumpang 1 memulai percakapan dengan mengajukan pertanyaan terhadap P2 mengenai kabar dengan berbahasa Jawa. Kemudian dijawab kembali oleh P2 dengan berbahasa Jawa kembali. Pemilihan penggunaan bahasa Jawa dilakukan sebagai bentuk penyesuai penggunaan bahasa P1 oleh P2. Pada perkembangan percakapan berikutnya P2 membutuhkan perpindahan penggunaan bahasa dari bahasa Jawa ke bahasa Jawa Kromo. Perpindahan penggunaan ragam bahasa Jawa Kromo karena penutur memiliki keinginan untuk menghormati lawan bicaranya yang berusia lebih tua darinya sehingga digunakan bahasa halus sebagai sarana dalam berkomunikasi dan menyesuaikan terhadap bahasa yang digunakan oleh lawan bicaranya.

\section{Alih Kode Eksternal}

Suatu masyarakat penutur bahasa melakukan peeralihan penggunaan bahasa dalam berkomunikasi disebabkan karena terbatasnya kemampuan penggunaan kode atau bahasa penutur, sehingga ketika proses komunikasi berlangsung terjadi ketidakpahaman padanan satuan bahasa dasar yang dipakainya sehingga beralih ke bahasa yang lainnya. Hal tersebut tentu dapat menyebabkan penutur melakukan perpindahan penggunaan bahasa. Berikut ini data yang memuat kegiatan interaksi yang terjadi antarpenumpang dalam angkutan umum (elf) Jurusan Sindang-Terminal Harjamukti Cirebon memuat fenomena alih kode eksternal berupa perpindahan penggunaan bahasa dari bahasa Inggris ke bahasa Indonesia seperti pada data berikut ini.

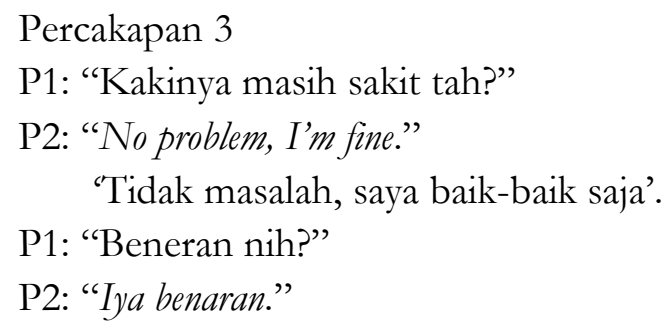

Interaksi yang terjadi antarpenumpang dalam angkutan membahas mengenai pertanyaan tentang keadaan kaki P2. Berdasarkan data tersebut, dapat diketahui bahwa bahasa Indonesia dipilih oleh P1 dalam pembukaan percakapan dengan P2 yang berisi mengenai pertanyaan tentang keadaan kaki P2 yang habis jatuh terkilir dari tangga. Setelah itu, dijawab oleh P2 dengan berbahasa Inggris "No problem, I'm fine" yang berarti "Tidak masalah, saya baik-baik saja". Pemilihan kode bahasa Inggris dilakukan karena penutur memiliki keinginan untuk menggunakan bahasa yang lebih kekinian. Menurutnya, dalam kegiatan interaksi dengan berbahasa Inggris akan dipandang sebagai manusia kekinian yang berpengetahuan tinggi. Akan tetapi dalam perkembangan percakapan berikutnya, P2 membutuhkan peralihan penggunaan bahasa dalam berkomunikasi dari bahasa Inggris ke bahasa Indonesia, seperti pada kutipan "Iya benaran". Peralihan penggunaan bahasa dilakukannya karena P2 kehabisan penguasaan kode bahasa Inggris dalam berkomunikasi 
karena kemampuannya yang lemah terhadap penguasaan bahasa Inggris sehingga digunakanlah kode bahasa Indonesia sebagai bentuk meyakinkan lawan bicaranya akan keadaan kakinya.

Selain alih kode ditemukan juga bentuk campur kode ke dalam pada tataran pengulangan kata, campur kode ke dalam pada tataran pada tataran kalusa, campur kode ke luar pada tataran frasa, campur kode ke luar bentuk idiom, dan campur kode campuran bentuk baster pada intaksi yang terjadi dalam angkutan umum (elf) Jurusan SindangTerminal Harjamukti Cirebon. Adapun faktor penyebabnya meliputi faktor penggunaan istilah yang lebih populer, maksud dan tujuan pembicara, untuk sekadar bergengsi, dan topik pembicaraan.

\section{Campur Kode ke Dalam Pada Tataran Kata}

Manusia dalam menjalankan kehidupan sehari-harinya di masyarakat terdapat kosakata tertentu yang dianggap populer. Kosakata populer dapat diukur dengan banyaknya masyarakat yang mengetahui kata tersebut. Dengan demikian, ketika seseorang berkomunikasi dan terdapat beberapa unsur bahasa dasar yang tidak diketahui atau tidak dikuasi maka digunakan padanan kata yang lebih populer yang diketahui oleh kedua pihak petutur. Dalam penelitian ini, ditemukan data berisi percakapan yang memuat peristiwa campur kode ke dalam berupa penyisipan unsur bahasa gaul ke dalam bahasa Indonesia. Hal ini terjadi disebabkan karena penutur memiliki keinginan untuk menggunakan bahasa yang kekinian yang sering digunakan dan diketahui serta dipahami oleh banyak orang termasuk lawan bicaranya.

Percakapan 4

P1: "Say, tadi kenapa lari-lari?"

P2: "Tidak napose-napose, Say. Takut ketinggalan angkutan saja yakin.”

'Tidak kenapa-kenapa, Say. takut tertinggal angkutan saja yakin'.

P1: "Santai saja sih say masih banyak ini kok. Segala sesuatunya harus dibawa baek-baek 'baik-baik' saja."

P1: "Iya, Say maaf."

Percakapan yang terjadi antarpenumpang dalam angkutan umum terdapat penggunaan penyisipan unsur bahasa gaul oleh $\mathrm{P} 2$, seperti pada kata napose-napose. Kata napose-napose dikategorikan sebagai ragam kata kekinian karena banyak digunakan dikalangan remaja. Selain kalangan ramaja, kata napose-napose juga sering digunakan oleh artis dalam pertelevisian pada acara santai. Kata napose-napose sepadan dengan kata kenapa-kenapa dalam bahasa Indonesia. Kata napose-napose merupakan bentuk pengulangan kata yang dari kata dasar napose sepadan dengan kata kenapa dalam bahasa Indonesia bermakna kata tanya untuk menanyakan sebab atau alasan. Kemudian kata tersebut mendapat pengulangan secara keseluruhan sehingga menjadi kata napose-napose yang sepadan dengan kata kenapakenapa dalam bahasa Indonesia berarti kata untuk mengungkapkan kekhawatiran akan terjadinya peristiwa yang tidak diharapkan. Campur kode terjadi disebabkan karena penutur atau P2 berkeinginan untuk menggunakan bahasa kekinian yang sering digunakan dan diketahui serta dipahami oleh banyak orang termasuk lawan bicaranya. Penggunaan bahasa kekinian dilakukan sebagai bentuk pengeksisan diri terhadaap perkembangan penggunaan bahasa ragam. 


\section{Campur Kode ke Dalam Pada Tataran Klausa}

Berikut ini contoh peristiwa tutur yang memuat fenomena campur kode ke dalam pada tataran klausa berupa penyisipan unsur bahasa Jawa ke dalam bahasa Indonesia. Hal ini disebabkan karena fungsi dan maksud pembicaraan. Seseorang dalam berkomunikasi memiliki maksud tertentu, salah satu maksdnya, yaitu agar terlihat keren karena dapat menyesuaikan pembicaraan dengan lawan bicaranya.

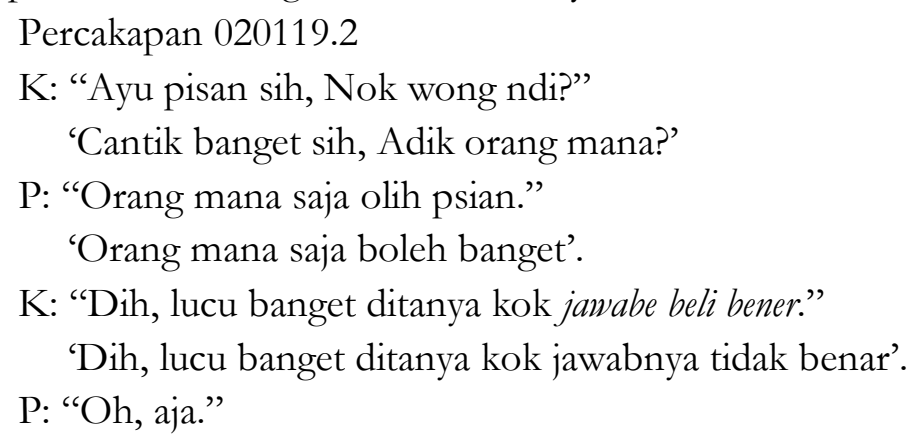

Pada percakapan tersebut ditemukan peristiwa campur kode ke dalam berupa penyisipan unsur bahasa Jawa ke bahasa Indonesia yang dilakukan oleh kondektur, seperti pada klausa Jawabe beli bener sepadan dengan klausa Jawabnya tidak benar dalam bahasa Indonesia. Berdasarkan data di atas, terdapat kata jawabe sepadan dengan kata jawabnya menduduki fungsi sebagai subjek dan kata beli bener sepadan dengan kata tidak benar berkedudukan sebagai predikat. Fenomena campur kode terjadi karena penutur atau kondektur memiliki maksud dan tujuan tertentu dalam berkomunikasi. Maksud dan tujuan penutur dalam melakukan pencampuran penggunaan kode bahasa karena penutur memiliki keinginan untuk melakukan penyesuaian penggunaan bahasa lawan bicaranya. Lawan bicara dalam berkomunikasi mendahului melakukan campur kode anatar bahasa Jawa dengan bahasa Indonesia kemudia penutur melakukan penyesuaian penggunaan pencampuran bahasa sama seperti lawan bicaranya. Hal ini dilakukan dengan tujuan agar penumpang dapat merasa nyaman ketika berkomunikasi dengan kondektur sehingga memudahkan kondektur menjalin hubungan kerja sama yang baik dengan penumpang. Kerja sama yang dimaksudkan adalah penumpang bersedia menjadi pelanggan di angkutan umumnya, dan kondektur bersedia memberikan tarif angkutan yang tidak terlalu mahal pada penumpangnya.

\section{Campur Kode ke Luar Pada Tataran Frasa}

Berikut ini terdapat percakapan yang menunjkkan terjadinya campur kode ke luar pada tataran frasa berupa penyisipan unsur bahasa Inggris ke dalam bahasa Indonesia oleh sopir angkutan umum. Hal ini disebabkan karena pembicara berkeinginan untuk memperlihatkan kemampuannya kepada lawan bicaranya serta penumpang yang ada bahwa meskipun hanya seorang sopir tetapi mampu berkomunikasi dengan menggunakan bahasa Inggris.

Percakapan 5

K: "Si Ade kemana sih? Capek mau gantian!"

S: "Tadi sih katanya lagi on the way."

'Tadi sih katanya sedang dalam perjalanan'.

K: "Geuning, lama banget."

'Kok, lama banget'. 
Data tersebut merupakan percakapan yang terjadi antara sopir dengan kondektur dalam angkutan umum. Pada percakapan tersebut terdapat ungkapan sopir yang mencampurkan penggunaan bahasa dalam berkomunikasi berupa penyisipan unsur bahasa Inggris ke dalam bahasa Indonesia oleh sopir dalam angkutan umum (elf) Jurusan SindangTerminal Harjamukti Cirebon. Berdasarkan data di atas, ditemukan bentuk penyisipan unsur bahasa Inggris pada kata on the way yang berarti lagi di jalan atau sedang dalam perjalanan. Kata sedang dalam perjalanan berkedudukan sebagai bentuk kata atau frasa verba. Hal ini disebabkan karena faktor untuk sekadar bergengsi. Pembicara berkeinginan untuk memperlihatkan kemampuannya kepada lawan bicaranya serta penumpang yang ada bahwa meskipun hanya seorang sopir tetapi mampu berkomunikasi dengan menggunakan bahasa Inggris. Meskipun pendidikannya hanya tamatan sekolah dasar tetapi sopir mampu menggunakan bahasa Inggris dalam berkomunikasi. Bahasa Inggris dipelajarinya melalui aplikasi kamus bahasa Inggris yang ada telepon genggamnya.

\section{Campur Kode ke Luar Pada Tataran Bentuk Idiom}

Campur kode ke luar pada tataran bentuk idiom merupakan penyisipan unsur bahasa lain ke bahasa asal berupa penyisipan bentuk ungkapan. Campur kode ke luar pada tataran bentuk idiom atau ungkapan ditemukan pada data yang memuat kegiatan percakapan antarpenumpang dalam angkutan umum. Campur kode terjadi disebka karena penutur memiliki keinginan untuk dapat mengikuti pengguaan istilah yang lebih populer.

\section{Percakapan 6.1}

P1: "Hai, Sis."

'Hai, saudara perempuan'.

P2: "Hai, say. Baru ketemu nih, gimana kabarnya?"

P1: "Wih alkhamdulillah. By the way mau on the way ke mana?"

'Wah, alhamdulilah. Ngomong-ngomong mau jalan-jalan ke mana'?

P2: "Th, gue mau refreshing nih."

'Th, saya mau liburan atau menyegarkan pikiran nih'.

P1: "Ikut dong, Cuy."

'Ikut dong, say'.

P2: "Yuk, kuy."

'Yuk, yuk'.

Pada data tersebut menunjukkan terjadinya fenomena pencampuran penggunaan unsur bahasa berupa penyisipan unsur bahasa Arab ke dalam bahasa Indonesia oleh penumpang 1. Berdasarkan data di atas, ditemukan bentuk penyisipan kata dalam bahasa Arab seperti pada kata alkhamdulillab” yang sepadan dengan kata dalam bahasa Indonesia alhamdulillah" yang berarti pengungkapan pujian kepada Allah Swt. Penggunaan penyisipan unsur bahasa Arab dianggap populer karena banyak yang mengetahui dan menggunakan bentuk kata idiom alhamdulillah sebagai bentuk pujian kepada Tuhannya. Campur kode ke dalam pada tataran bentuk idiom terjadi disebabkan karena penutur ingin menggunaan bahasa yang populer dengan melakukan penyisipan bahasa asing. Bahasa Arab dipilihnya karena populer di kalangan masyarakat, bahasa Arab selain banyak yang memahami makna dari penyisipan bahasa yang digunakan juga banyak yang menggunakannya ketika penutur bahasa memiliki keinginan untuk memuji Tuhannya. 


\section{Campur Kode Campuran Pada Tataran Baster}

Campur kode pada tataran baster merupakan penyelipan unsur satuan bahasa berupa gabungan pembuntukan antara bahasa asli atau dasar dengan bahasa asing atau antarbahasa dasar yang berlainan. Percakapan di bawah ini terdapat fenomena pencampuran penggunaan bahasa berupa penyisipan unsur bahasa Arab, dan bahasa Inggris ke dalam bahasa Indonesia oleh P1 dalam angkutan umum. Hal ini disebabkan kerena penutur hendak menyesuaikan bahasa yang digunakan dengan topik pembicaan yang berlangsung, dimana topik pembicaraan membahas mengenai basa-basi penutur terhadap lawan bicaranya sehingga atau obrolan santai antarpeserta tutur dalam angkutan umum sehingga dilakukan penggunaan pencampuran bahasa.

Percakapan 6.2

P1: "Hai, Sis."

'Hai, saudara perempuan'.

P2: "Hai, Say. Baru ketemu nih, gimana kabarnya?"

P1: "Wah, alkhamdulillah. By the way mau on the way ke mana?"

"Wah, alhamdulillah. Ngomong-ngomong mau jalan-jalan ke mana?

P2: "Ih, gue mau refreshing nih."

'Th, saya mau liburan atau menyegarkan pikiran nih'.

P1: "Ikut dong, Cuy."

'Ikut dong, Say'.

P2: "Yuk, kuy."

'Yuk, yuk'.

Peristiwa tutur yang terjadi antarpenumpang dalam angkutan umum mengandung terjadinya penggunaan penyisipan unsur bahasa Arab dan bahasa Inggris ke dalam bahasa Indonesia oleh P1. Penyisipan kata dalam bahasa Arab ditemukan penggunaan kata alhamdulillah yang sebanding dengan kata dalam bahasa Indonesia alhamdulillah bermakna pengungkapan pujian kepada Allah Swt. Kemudian, penggnaan penyisipan unsur bahasa Inggris seperti pada kata by the way yang berarti ngomong-ngomong merupakan bentuk campur kode tataran pengulangan kata berkedudukan sebagai bentuk kata atau frasa verba. Setelah itu, terdapat pula penggunaan penyisipan kata on the way dari bahasa Inggris yang berarti lagi di jalan atau sedang dalam perjalanan atau jalan-jalan. Kata jalan-jalan merupakan bentuk campur kode tataran pengulangan kata berkedudukan sebagai bentuk kata atau frasa verba. Penutur melakukan campur kode disebabkan karena topik pembicaraan. Berhubung dalam percakapan tersebut membahas mengenai basa-basi penutur terhadap lawan bicaranya atau obrolan santai antarkedua peserta tutur dalam angkutan umum sehingga bahasa yang digunakan adalah bahasa bebas yang tidak terikat kaidah atau bahasa campuran. Dengan demikian penggunaan penyisipan bahasa lain dalam berkomunikasi dilakukan dengan tujuan agar dapat membangun suasana komunikasi yang menyenangkan sesuai dengan topik pembicaraan.

\section{SIMPULAN}

Simpulan dari hasil penelitian ini adalah sebagai beriku: Pertama, bentuk alih kode dalam angkutan umum (elf) Jurusan Sindang-Terminal Harjamukti Cirebon meliputi alih kode 
internal yang mencakup alih kode internal antarbahasa dan alih kode internal antarragam bahasa serta alih kode ksternal. Kedua, faktor penyebab terjadinya alih kode adalah lawan bicaranya memiliki latar belakang bahasa yang berbeda penutur, penutur memiliki keinginan untuk menghormati lawan bicaranya yang berusia lebih tua darinya, dan keterbatasan penggunaan kode. Ketiga, bentuk campur kode dalam angkutan umum (elf) Jurusan Sindang-Terminal Harjamukti Cirebon meliputi campur kode ke dalam pada tataran pengulangan kata, campur kode ke dalam pada tataran pada tataran kalusa, campur kode ke luar pada tataran frasa, campur kode ke luar bentuk idiom, dan campur kode campuran bentuk baster pada intaksi yang terjadi dalam angkutan umum (elf) Jurusan SindangTerminal Harjamukti Cirebon. Keempat, faktor penyebab campur kode terjadi adalah penutur berkeinginan untuk dapat menggunakan istilah yang lebih populer, penutur memiliki maksud dan tujuan tertentu dalam pembicaraan, untuk sekadar bergengsi, dan penyesuaian penggunaan bahasa dengan topik pembicaraan.

\section{DAFTAR PUSTAKA}

Azwar, S. (2009). Metode Penelitian. Bandung: Pustaka Pelajar.

Chaer, A. (2015). Linguistik Umum. Jakarta: Rineka Cipta.

Chaer, A., \& Agustina, L. (2010). Sosiolinguistik Perkenalan Awal. Jakarta: Rineka Cipta.

Itaristanti. (2012). Bahasa dan Kelas Sosial: Studi Kasus Variasi Bahasa Sopir dan Kondektur. Edueksos, I(Jurnal Edueksos Vol I No 1, Januari-Juni 2012), 127. Retrieved from

http://www.syekhnurjati.ac.id/jurnal/index.php/edueksos/article/view/620/537

Jendra, M. I. I. (2012). Sociolinguistic. Yogyakarta: Graha Ilmu.

Kholiq, A., Roekhan, \& Sunaryo. (2013). Campur Kode Pada Naskah Pidato Presiden Republik Indonesia Bapak Dr. H. Susilo Bambang Yudhoyono. Jurnal Pendidikan Bahasa Dan Sastra Indonesia Online, 1(1), 1-11. Retrieved from http://jurnalonline.um.ac.id/data/artikel/artikelD30F1E25F967C7B4E28B779D503C4A5A.pdf Mahsun. (2017). Metode Penelitian Bahasa: Tahapan Strategi, Metode, dan Tekniknya. Jakarta: Raja Grafindo Persada.

Mustikawati, D. A. (2015). Alih Kode dan Campur Kode Antara Penjual dan Pembeli (Analisis Pembelajaran Berbahasa Melalui Studi Sosiolinguistik). Jurnal Dimensi Pendidikan Dan Pembelajaran, 3(2), 23-32. Retrieved from http://journal.umpo.ac.id/index.php/dimensi/article/view/154

Rokhman, F. (2013). Sosiolinguistik. Yogyakarta: Graha Ilmu.

Suandi, I. N. (2014). Sosiolinguistik. Yogyakarta: Graha Ilmu.

Sudaryanto. (2015). Metode dan Aneka Teknik Analisis Bahasa. Yogyakarta: Duta Wacana University Press.

Sugiyono. (2015). Metode Penelitian Pendidikan: Pendekatan Kuantitatif, Kualitatif, dan $R \& D$ (cetakan ke). Bandung: Alfabeta.

Sugiyono. (2016). Metode Penelitian Kuantitatif, Kualitatif, dan R\&D. Bandung: Alfabeta. 